\title{
Concordance of HER-2/Neu over Expression with Steroid Receptor Status in Female Breast Cancers
}

\author{
Mohamed Salah Abdelhamid"1, Solafa Amin Abdelaziz², Sahar Ali Daoud', \\ Ahmed Mohamed Sadat' ${ }^{1}$, Ayman Refaat Abdelhaseeb1, Tamer Mohamed Nabil'1, \\ Mohamed Salah Abdelbasset ${ }^{1}$, Hesham Ahmed Nafady', Khaled Ahmed Shawky ${ }^{1}$, \\ Mohamed Hasssen Abdelmoola ${ }^{1}$ \\ ${ }^{1}$ Benisuef Faulty of Medicine, Benisuef, Egypt \\ ${ }^{2}$ Kasr Al Aini Faculty of Medicine, Cairo, Egypt \\ Email: mohamedsalah_2000@hotmail.com
}

Received 24 May 2014; revised 23 June 2014; accepted 21 July 2014

Copyright (C) 2014 by authors and Scientific Research Publishing Inc. This work is licensed under the Creative Commons Attribution International License (CC BY). http://creativecommons.org/licenses/by/4.0/

(c) (i) Open Access

\section{Abstract}

HER-2/neu over expression is associated with increased tumor aggressiveness, increased rates of recurrence, and increased mortality in node positive patients. It is amplified and/or over expressed in approximately $30 \%$ of female breast cancers. This study was to detect the relation between HER-2/neu over expression and steroid hormone receptor status. It was conducted at Cairo and Bani Suif university hospitals between February 2012 to February 2014. HER-2/neu over expression was found to be positive in thirteen patients $(41 \%)$ out of the thirty two patients included in the study, more positive (52\%) HER-2/neu was found among estrogen receptor (ER) positive patients, on the other hand, only $18 \%$ positive HER-2/neu was detected among ER negative patients. This difference was statistically significant $(P<0.03)$. The same outcome was with progesterone receptors $(P R)$ and HER-2/neu with statistically significant difference also $(P=0.02)$. Conclusion: HER-2/neu over expression is strongly related to ER and PR, this was more evident in negative steroid receptors status. The failure of treatment in positive steroid receptors could be explained by HER-2/neu positivity.

\section{Keywords}

HER-2/Neu, ER, PR 


\section{Introduction}

The natural secretory products of the mammary epithelial cell, colostrum and milk, are abundant sources of growth factors [1]. Growth factors in the normal gland probably serve multiple purposes in the newborn development, mammary growth, and mammary carcinogenesis. A large body of literature has shown that estrogen, antiestrogen, progesterone and anti progesterone strongly regulates certain growth factors [2]. The autocrine model of tumor genesis holds that tumor formation, like the process of embryogenesis, occurs through a coordinated series of cellular signaling events, regulated by growth factors. Transformation of normal cells to malignant ones may result from either increased production of stimulatory growth factors or decrease production of inhibitory growth factors [3].

Expression of estrogen receptors and progesterone receptors within tumors correlates well with low histologic grade and responsiveness to hormone manipulation, especially in postmenopausal patients [4]. No much correlation exists between the cytoarchitectural type of breast carcinoma and presence of hormone receptor protein, no statistically significant difference has been found between ductal type and lobular type tumors [5]. Because the growth of breast cancer is often regulated by the female sex steroids, the determinations of the cellular concentrations of ER and PR in the tumor are currently used to predict which patients are of good prognosis as they may also benefit from antihormonal therapy [6]. The ER cannot be clearly classified as an oncoprotein or tumor suppressor protein, although it clearly mediates onset and progression of the disease. In striking contrast to its normal function in ER-positive cell lines, ER expressed in ER-negative cell lines functions to suppress cell growth, in spite of its normal action to regulate expression of certain hormonally responsive genes, thus the multiple differences between ER positive and ER negative breast cancer appear to include incompatible growth regulatory mechanisms [7]. However, there is only $8 \%$ to $20 \%$ absolute difference in disease free survival between women with ER-positive node negative invasive breast carcinoma and those with ER-negative disease and some studies have shown that any survival advantage of ER-PR positivity is lost after 5 years of follow up [4].

More than $60 \%$ of breast cancer patients are ER-positive tumors, and respond to endocrine therapy. In addition, $5 \%$ to $10 \%$ of the patients designated ER-negative appear to initially respond to endocrine therapy [6]. To improve the value of determination of the ER for tumor prognosis, the presence of the estrogen-regulated PR protein is now routinely determined. In many breast tumor cell lines and in normal, ER containing tissue, such as endometrium and brain, PR expression also has been shown to be positively regulated by estrogen [3].

It is still not known whether ER regulates PR in normal human mammary epithelium or if ER and PR are coexpressed in the same subpopulation of ductal and lobular luminal cells, although the former is likely. $70 \%$ of PR positive and $25 \%$ to $30 \%$ of PR negative tumors respond to hormone therapy. The reasons for these discrepancies are unclear but may include laboratory error, differential metabolism of tamoxifen, the ability of mutated ER or PR to regulate gene expression in the absence of ligand [7].

In some tumors, loss of normal growth regulation occurs as a result of altered expression of growth factor receptors. Either constitutive activation of a growth factor receptor or an increase in growth factor receptor number would have the same effect as an increase in levels of the corresponding growth factor [2]. The c-erb-B2 (HER-2/neu) oncogene product is a transmembrane receptor similar to epidermal growth factor(EGF) receptor except that it is constitutively activated that is to generate a mitogenic signal in the absence of EGF binding [3]. The c-erb-B-2 proto-oncogene is located on $17 \mathrm{q} 21$, with intrinsic tyrosine kinase activity homologous to EGF receptor. It is amplified and/or over expressed in approximately 30\% of human breast tumors [6]. Over expression is associated with increased tumor aggressiveness, increased rates of recurrence, and increased mortality in node positive patients, while the influence in node negative patients is more variable. It may also have a predictive role for response to chemotherapy and endocrine therapy. It may be associated with resistance to alkylatorbased chemotherapy [8].

When excess copies of the HER-2/neu gene are present gene amplification occurs and is associated in more than $90 \%$ of cases with increased expression or over expression of the HER-2/neu gene on the cell membrane (10 to 100 fold greater than that found in normal, adjacent breast epithelial membrane) [4].

\section{Patients and Methods}

This study was conducted at Caio and BaniSuif university hospitals between Feb. 2012 till Feb. 2014. Thirty two patients were enrolled in the study; all were females with breast mass presented in the outpatient department complaining of that mass, none of those masses were discovered through any medical organized programmes. 
Written approvals were taken from the patients to undergo this research. After approval from the ethical committee.

All patients were subjected to routine preoperative assessment with treating of any co-morbid disease especially in the older patients.

The initial procedures were lumpectomy or biopsy. The definitive was modified radical mastectomy, some after frozen sections, others after paraffine section. All the specimens were examined macroscopically to determine the site, size, absence or presence of other mass or masses. Microscopic examination with haematoxylin and eosin stains for histological typing (ductal-lobular-terminal ductal lobular unite) and if it was accompanied by insitu component, if it was invasive or was totally insitu, grading of the mass, and then detection of the hormonal status of the lesion (estrogen receptor-progesterone receptor HER2/neu receptor).

The operative interventions policy in the study were localized excision with safety margins for ductal carcinoma insitu(DCIS) (only one case) with no further treatment as the margins proved to be free. Modified radical mastectomy done for the others as definitive surgical treatment.

Detection of estrogen receptors was done using Dako, primary antibody, Code No. N1575, which are mouse anti-human estrogen antibody. This monoclonal antibody reacts with the $\mathrm{N}$-terminal domain region of human estrogen receptor. This product strongly labels the nucleus of cells known to contain abundant amounts of estrogen receptors. It is used with formalin fixed paraffine-embedded tissue sections $(4 \mu \mathrm{m})$ after treating the deparaffinized tissue sections with heat in a water bath prior to the immunohistochemical staining [9].

Detection of progesterone receptor was done using Dako, primary antibody, Code No. N1595 which are mouse antihuman progesterone antibody which stain the nuclei of cells from various histologic subtypes of breast carcinoma in a formalin fixed paraffin—embedded tissue sections $(4 \mu \mathrm{m})$ after treating the deparafinized tissue in a heat bath Anti-progesterone receptor has been demonstrated to stain the nuclei of cells of breast carcinoma [10].

Detection of HER-2/neu receptors was done using Dako antihuman c-erb B-2 oncoprotein Code No. A0485, this antibody labels an intra cellular domain of c-erb B-2 oncoprotein. The antibody can be used on paraffin embedded tissue sections fixed in formalin. Heat induced epitope retrieval in $10 \mathrm{mmol} / \mathrm{L}$ citrate buffer, $\mathrm{pH} 6.0$ or in Dako Target Retrieval Solution, Code No. S, 1700 Cells labeled specifically by the antibody display a staining confined to the cell membrane [11].

Statistical analysis is done using Fisher's test to obtain the Z-value and from the standardized table the degree of probability is obtained [12].

\section{Results}

Thirty two female patients were included in the study, their ages ranged from 25 years to 75 years with a mean \pm SD (standard deviation) of 48 years \pm 13.5 years.

Out of the thirty two cases enrolled in the study there were twenty one ER positive cases (Figure 1) (65\%), eleven cases (35\%) were ER negative (Figure 2), seventeen cases (53\%) were PR positive (Figure 3), fifteen (47\%) were PR negative (Figure 4), thirteen cases (41\%) were HER-2/neu positive (Figures 5-9), and nineteen (59\%) were HER-2/neu negative (Figure 10 and Figure 11) (Table 1).

Comparing the status of HER-2/neu in ER positive and ER negative patients (Table 2), it was 52\% and 18\% positive HER-2/neu in ER positive and ER negative respectively, while it was $48 \%$ and $82 \%$ negative HER-2/ neu in ER positive and ER negative patients respectively. This big difference in HER-2/neu negative patients was statistically significant $(\mathrm{P}<0.03)$.

Regarding the over expression of HER-2/neu among PR positive and negative, it was found that out of 17 cases PR positive 11 cases (65\%) were HER2/neu positive, while 4 cases (27\%) were HER-2/neu positive out of $15 \mathrm{PR}$ negative patients (Table 3$)$ and this was significant statistically $(\mathrm{P}=0.02)$.

\section{Discussion}

HER-2/neu is a member of the epidermal growth factor receptor family. Amplification or over expression of thisoncogene has been shown to play an important role in the development and progression of certain aggressive types of breast cancer. In recent years the protein has become an important biomarker and target of therapy for approx. 30\% of breast cancerpatients [13].

At present, about one in nine women, living to the age of 85 years, will develop breast carcinoma during her 


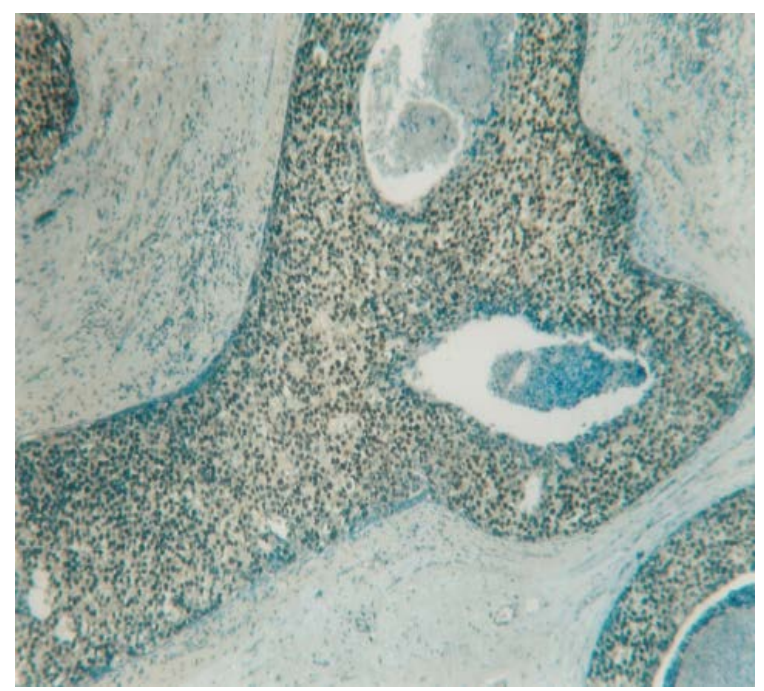

Figure 1. Insitu ductal carcinoma highly positive reaction for $\operatorname{ER}(250 \times)$.

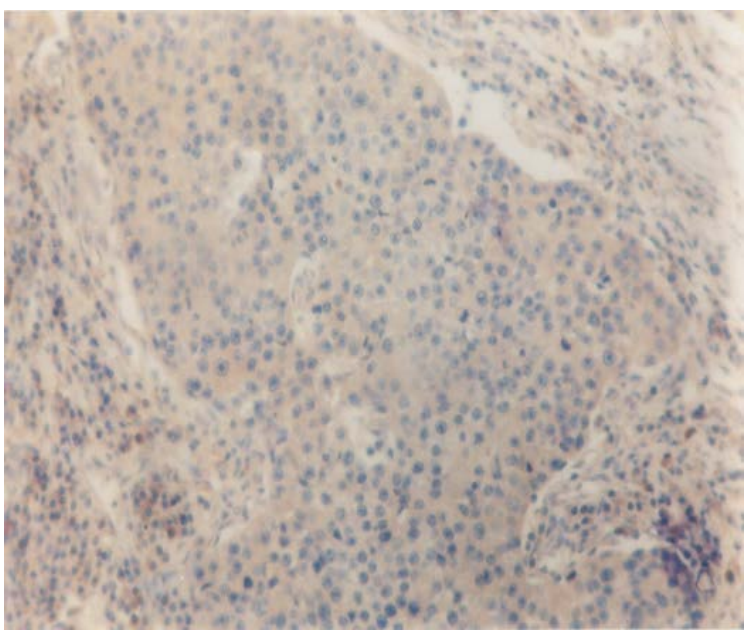

Figure 2. Infiltrating duct carcinoma, exhibiting negative reaction for ER $(250 \times)$.

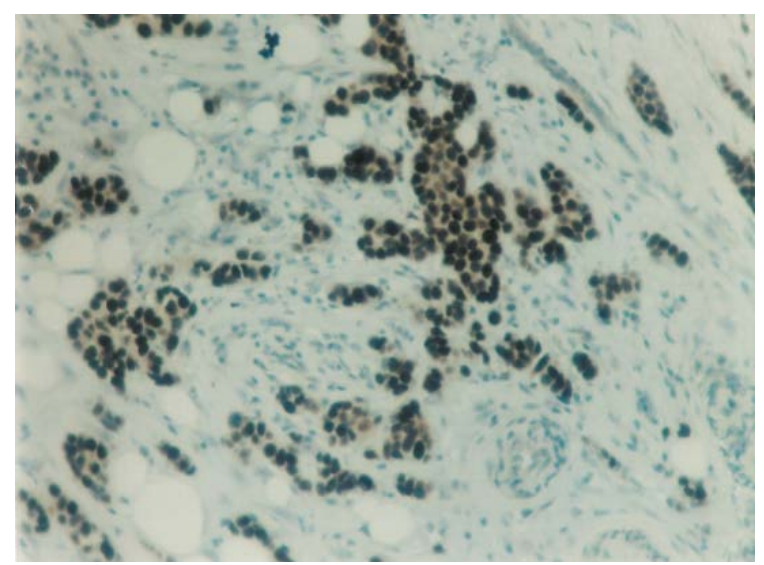

Figure 3. Highly positive immunostaining nuclear reaction for PR in infiltrating duct carcinoma $(100 \times)$. 


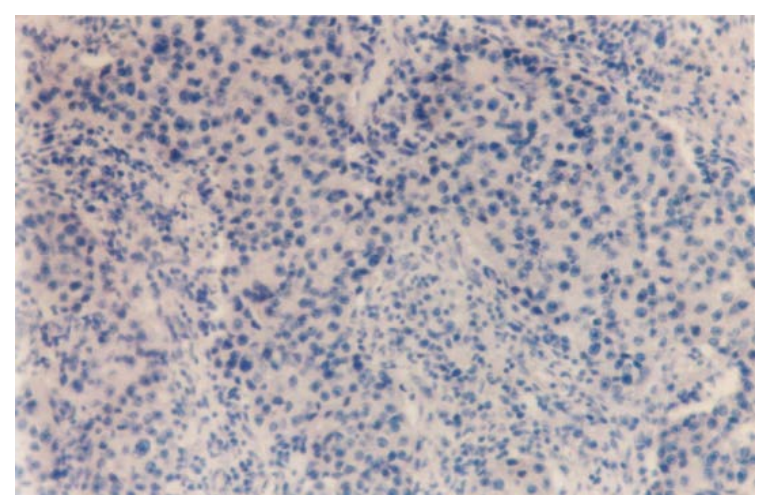

Figure 4. Infitrating duct carcinoma showing negative PR staining reaction $(250 \times)$.

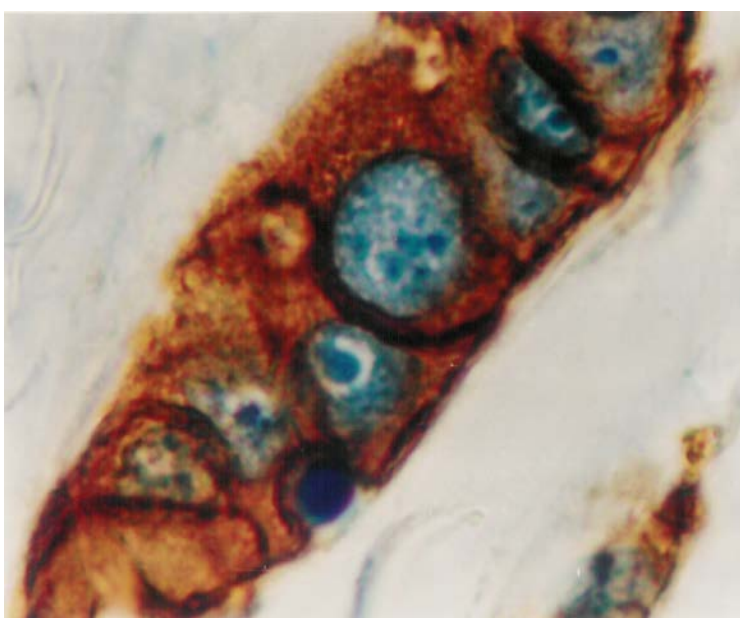

Figure 5. Infitrating duct carcinoma with strongly positive staining for HER-2/neu. Note: the strong membranous staining and the cytoplasmic as well $(1000 \times)$.

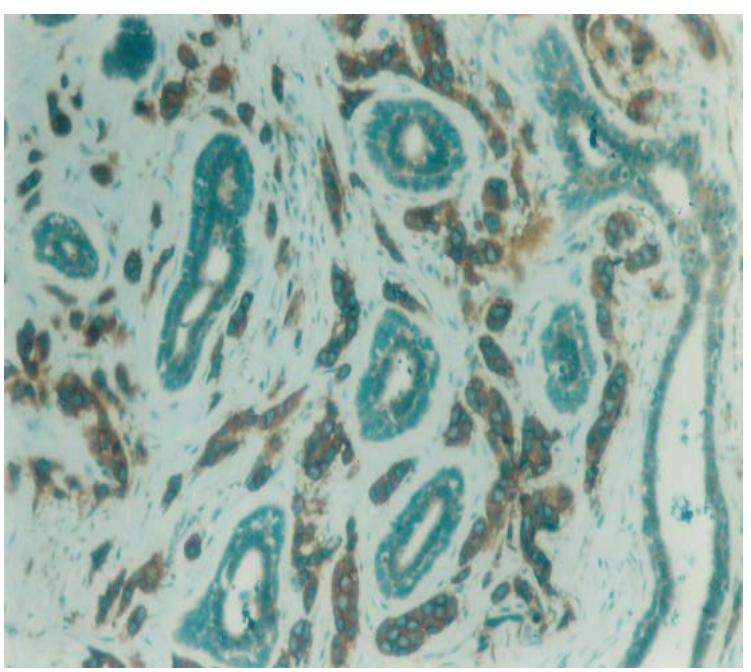

Figure 6. Infitrating duct carcinoma with moderate to strong positive staining for HER-2/neu receptors, compared to negative staining reaction seen in the intervening normal non neoplactic glands $(100 \times)$. 


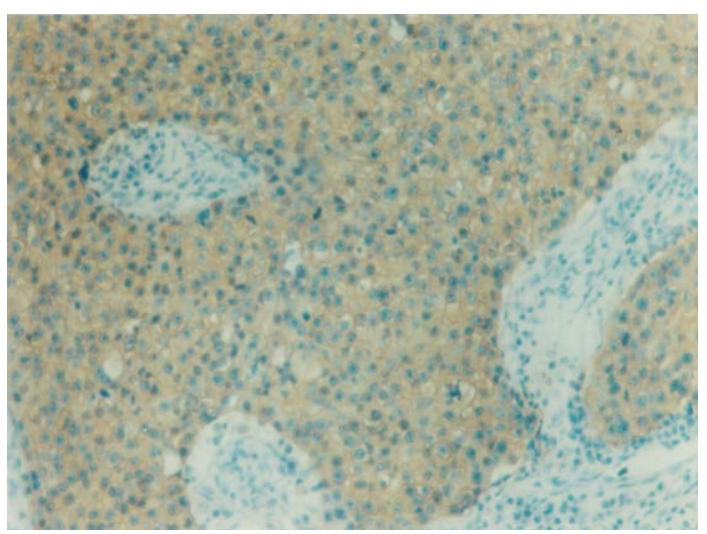

Figure 7. Infitrating duct carcinoma with mild positive staining reaction to HER-2/neu receptors (250×).

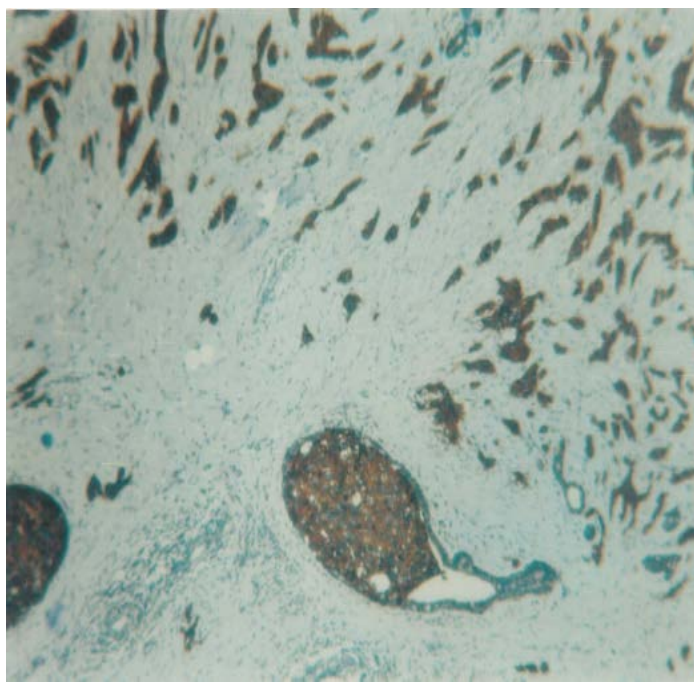

Figure 8. Infitrating duct carcinoma with intra ductal component showing strongly positive reaction for HER-2/neu $(100 \times)$.

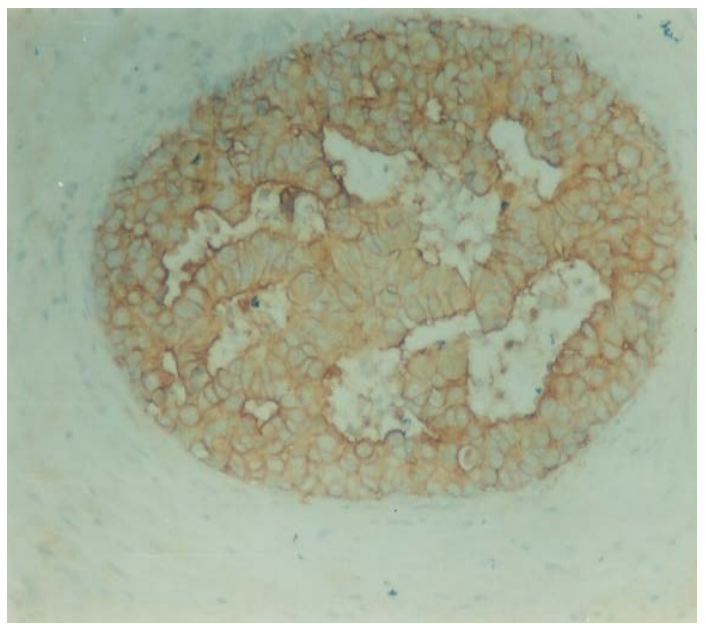

Figure 9. Intraductal carcinoma with moderate staining for HER-2/neu (250×). 


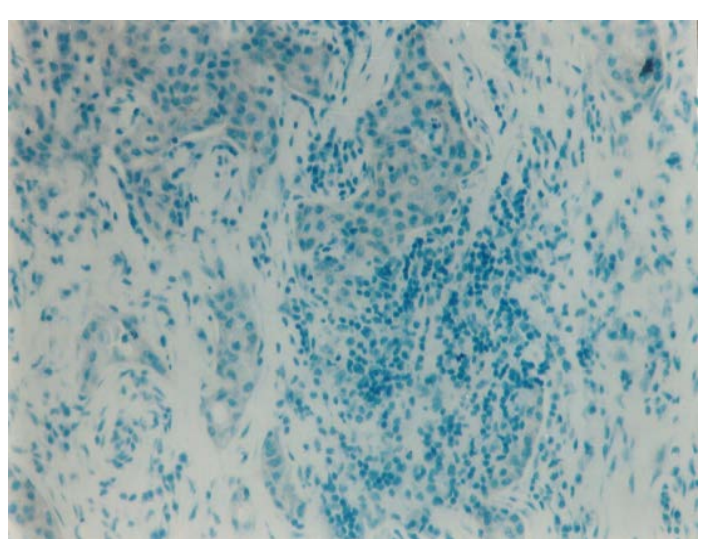

Figure 10. Infitrating duct carcinoma with negative staining reaction to HER-2/neu receptors, with considerable lymphocytic infiltrate $(100 \times)$.

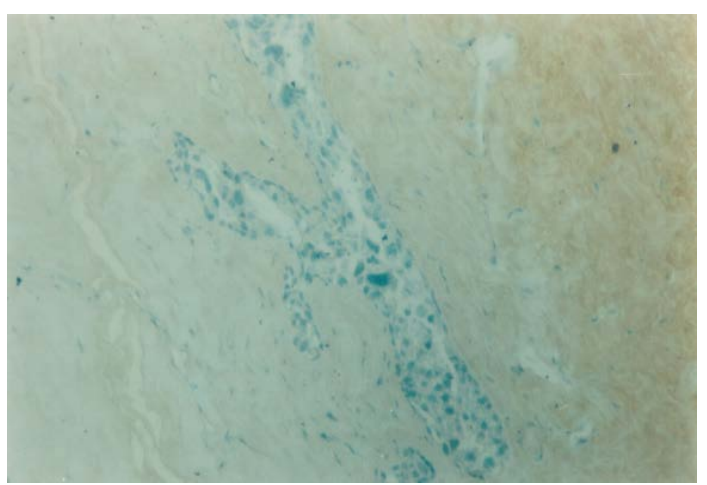

Figure 11. Intraductal carcinoma exhibiting negative immunestaining reaction for HER-2/neu receptors $(100 \times)$.

Table 1. Hormone receptor status.

\begin{tabular}{ccc}
\hline Receptor & Positive & Negative \\
\hline Estrogen & $21(65 \%)$ & $11(35 \%)$ \\
Progesterone & $17(53 \%)$ & $15(47 \%)$ \\
HER-2/neu & $13(41 \%)$ & $19(59 \%)$ \\
\hline
\end{tabular}

Table 2. ER to HER-2/neuover expression.

\begin{tabular}{ccccc}
\hline ER & NO & HER-2/neu positive & HER-2/neu negative & Statistics \\
\hline ER positive & 21 & $11(52 \%)$ & $10(48 \%)$ & $\mathrm{Z}=2.13$ \\
ER negative & 11 & $2(18 \%)$ & $9(82 \%)$ & $\mathrm{P}<0.03$ \\
\hline
\end{tabular}

Most of ER negative patients were Her-2/neu negative.

Table 3. PR to HER-2/neu over expression.

\begin{tabular}{ccccc}
\hline PR & NO & HER-2/neu positive & HER-2/neu negative & Statistics \\
\hline PR positive & 17 & $11(65 \%)$ & $6(35 \%)$ & $\mathrm{Z}=2.3$ \\
PR negative & 15 & $4(27 \%)$ & $11(73 \%)$ & $\mathrm{P}=0.02$ \\
\hline
\end{tabular}

Most of PR negative patients were Her-2/neu negative. 
lifetime. Moreover, with increased public awareness, more breast carcinomas are detected early, before axillary lymph nodes contain metastases. Two thirds of the invasive carcinoma will present with negative axillary lymph nodes. Recurrent tumors will develop in about $20 \%$ to $30 \%$ of patients with node negative invasive breast carcinoma and they are at risk of dying of disease. Those $20 \%$ to $30 \%$ of women who will have recurrence should be considered for aggressive adjuvant therapies. The remaining $70 \%$ to $80 \%$ probably need no further therapy because they appear to have been cured by surgery alone, this group need not be subjected to the inconvenient and toxic effect of aggressive adjuvant therapies. Pathologists can assess risk factors for development of recurrent tumors and provide valuable information to care for these patients. These risk factors include determination of lymph node status, tumor size, tumor type, histological grade, lymphatic vascular invasion, tumor proliferation rate and hormone receptor status [4].

HER2 proteins have been shown to form clusters in cell membranes that may play a role in tumor genesis The estrogen and progesterone receptors are dimeric gene regulatory proteins. The multiplicity of progesterone and estrogen receptor isoforms in breast cancer may allow for significant variations in patterns of dimerization and in resultant variations in specificity of ligand recognition with respect to agonist versus antagonist and differential regulation of target genes [14].

HER-2/neu positivity may activate ER expression through signaling kinases, and the combined target of mitogenic estrogen plus the monoclonal antibody therapy against HER-2/neu—over expressing tumors expand chances of survival for many patients. Being a developing country, with lack of specialized and optimally equipped health organizations, lack of health awareness and the cost for these tests were noted as limiting factors for access to basic health care service and resulted in advanced tumor grade at time of patient presentation [15].

Estrogen receptors were positive in twenty one cases (65\%) in the study, Progesterone receptors were positive in 17 patients (53\%), it. Generally speaking estrogen receptors were positive in $65 \%$ of our patients, while progesterone receptors were positive in 53\%, and HER-2/neu receptors were positive in $41 \%$. These finding goes hand in hand with many who found estrogen to be positive in about $60 \%$ of female breast carcinoma and HER-2/neu to be over expressed in 30\% - 35\% in breast carcinoma [7] [8] [16].

In estrogen positive patients (21 patients), eleven of them (52\%) were HER-2/neu positive, on the other hand $18 \%$ of estrogen negative were HER-2/neu positive, this finding was statistically significant $(\mathrm{P}<0.03)$.

This might explain why some ER positive do not respond well to hormonal manipulation as they might be HER-2/neu positive, on the other hand some ER negative respond well to hormone manipulation as they are HER-2/neu negative.

In progesterone positive patients, there were 11 (65\%) patients HER-2/neu positive, while there were 27\% (4) patient HER-2/neu positive among the progesterone negative patients, this finding were statistically significant $(P=0.02)$ and this was more or less the same like the relation mentioned before between HER-2/neu and estrogen. It seems that progesterone is under the direct effect of estrogen, or both estrogen and progesterone have the same relation with HER-2/neu expression. Pierce et al. [17] found no relation between ER, PR and HER-2/neu over expression, but in the current study, it is very evident that HER-2/neu over expression follow both estrogen and progesterone as in positive ER and PR there were 52\% and 65\% positive HER-2/neu, while in negative ER and PR there were $82 \%$ and $73 \%$ negative HER-2/neu, this finding was statistically significant. These more or less immuno reactivity pattern were more evident in the negative hormone status [18]. It can be stated that breast cancer cells that present with positive steroid hormone receptors with HER-2/neu over expression, may experience no response to anti-steroid therapy, owing to HER-2/neu over expression. This was in pre-herceptin era, now a day the outcome in improving due to the effect of herception [19]. On the other hand, patients with negative steroid hormone receptors and over expression of HER-2/neu, will have wild tumors biologically as they lost the effect of steroid receptors with its partial control on cell division with very aggressive course due to HER-2/neu over expression with early metastasis and recurrence [20] [21].

\section{Conclusions}

We concluded that HER-2/neu over expression was strongly related to ER and PR as both were statistically significant and this relation was very evident when either ER or PR was negative. The positive cases in case of positive steroid receptor may explain the failure of treatment

The objective of this paper was to study HER-2/neu receptor status in relation to that of steroid hormone receptors. 


\section{References}

[1] Grosvor, C.E. and Picciano, F.C. (2005) Hormones and Growth Factors Milk. Endocrine Reviews, 61, $413-417$.

[2] Vonderhaar, B.K. (2003) Regulation of Development of Mammary Gland. Cancer Treatment and Research, 40, 551559.

[3] Daly, J.M., Bertagnolli, M., Decosse, J.J., et al. (1999) Oncology. In: Schwartz, S.I., Ed., Principles of Surgery, 7th Edition, Mc Grow-Hill, New York, 297-360.

[4] Weiss, L.M. (2003) Breast. In: Weidner, N., Cote, R.J., and Weiss, L.M., Eds., Modern Surgical Pathology, 1st Edition, Saunders, Philadelphia, 599-672.

[5] Rosai, J. (2004) Breast. In: Rosai, J., Ed., Rosai and Acker Man’s Surgical Pathology, 9th Edition, Mosby, Edinburgh, 1763-1876.

[6] Licznar, A., Caporali, S., Lucas, A., et al. (2003) Identification of Genes Involved in Growth Inhibition of Breast Cancer. FEBS Letters, 23, 445-450. http://dx.doi.org/10.1016/S0014-5793(03)01090-1

[7] Dickson, R.B. and Lippman, M.E. (1997) Cancer of the Breast. In: Devita, V.T., Hellman, S. and Rosenberg, S.A., Eds., Cancer, 5th Edition, Lippincott, Philadelphia, 1541-1553.

[8] Cianfrocca, M. and Goldstein, L.J. (2004) Prognostic and Predictive Factors in Early Stage Breast Cancer. The Oncologist, 9, 606-616. http://dx.doi.org/10.1634/theoncologist.9-6-606

[9] Al Saati, T. (1993) Production of Monoclonal Antibodies in Human Oestrogen Protein Recptor. International Journal of Cancer, 55, 651. http://dx.doi.org/10.1002/ijc.2910550423

[10] Kell, D.L. (2003) Immunohistochemical Analysis of Breast Carcinoma Estrogen and Progesterone Receptor. Applimmunohisch, 1, 275.

[11] Koeppen, H.K.W., Wright, B.D., Burt, A.D., et al. (2001) Over Expression of HER-2-Neu an Immunohistochemical Survey. Histopathology, 38, 96-104. http://dx.doi.org/10.1046/j.1365-2559.2001.01084.X

[12] Swinscow, T.D.V. and Campell, M.J. (1996) Statistics at Square One. In: Swinscow, T.D.V., Ed., 9th Edition, Plymouth Latimer Trend Company Ltd., 1-139.

[13] Mitri, Z., Constantine, T. and O’Regan, R. (2012) The HER2 Receptor in Breast Cancer: Pathophysiology, Clinical Use, and New Advances in Therapy. Chemotherapy Research and Practice, 2012, Article ID: 743193. http://dx.doi.org/10.1155/2012/743193

[14] Kaufmann, R., Müller, P., Hildenbrand, G., Hausmann, M. and Cremer, C. (2011) Analysis of Her2/Neu Membrane Protein Clusters in Different Types of Breast Cancer Cells Using Localization Microscopy. Journal of Microscopy, 242, 46-54. http://dx.doi.org/10.1111/j.1365-2818.2010.03436.x

[15] Nyagol, J., Nyong’o, A., Byakika, B., Muchiri, L., Cocco, M., de Santi, M.M., Spina, D., Bellan, C., Lazzi, S., Kostopoulos, I., Luzi, P. and Leoncini, L. (2006) Routine Assessment of Hormonal Receptor and Her-2/Neu Status Underscores the Need for More Therapeutic Targets in Kenyan Women with Breast cancer. Analytical and Quantitative Cytology and Histology, 28, 97-103.

[16] Schmitt, F.C., Figueiredo, P. and Lacarda, M. (1995) Exxpression of C-erb B-2 Protein and DNA Ploidy in Breast Carcinogenesis. Archives of Pathology Laboratory Medicine, 119, 815-820.

[17] Pierce, L.J., Merino, M.J., D’angelo, et al. (1994) Is C-erb B-2 a Predictor for Recurrent Disease in Early Stage Breast Cancer. International Journal of Radiation Oncology * Biology * Physics, 28, 395-403. http://dx.doi.org/10.1016/0360-3016(94)90063-9

[18] Wang, W., Saluaga, R., et al. (2003) Gene Expression Signature Associated with Clinical Outcome in Breast Cancer. British Cancer Research, 82, 29-34.

[19] Huang, H.J., Neven, P., Drij Koningen, M., et al. (2005) Association between HER-2-Neu and Progesterone Receptor in Oestrogen Dependent Breast Cancer Is Age Related. Breast Cancer Research and Treatment, 91, 81-87. http://dx.doi.org/10.1007/s10549-004-8235-8

[20] O’ Malley, F.P., Saad, Z., Kerkuliet, N., et al. (1996) The Predictive Power of Semi Quantitative Immunohistochemial Assessment of p53 and c-erb B-2 in Lymph Node Negative Breast Cancer. Human Pathology, 27, 955-963. http://dx.doi.org/10.1016/S0046-8177(96)90224-5

[21] Jing, X., Kakudo, K., Murakami, M., et al. (1999) Intraductal Spread of Breast Carcinoma Has a Positive Correlation with C-erb B-2 over Expression. Cancer, 86,439-448. http://dx.doi.org/10.1002/(SICI)1097-0142(19990801)86:3<439::AID-CNCR12>3.0.CO;2-U 
Scientific Research Publishing (SCIRP) is one of the largest Open Access journal publishers. It is currently publishing more than 200 open access, online, peer-reviewed journals covering a wide range of academic disciplines. SCIRP serves the worldwide academic communities and contributes to the progress and application of science with its publication.

Other selected journals from SCIRP are listed as below. Submit your manuscript to us via either submit@scirp.org or Online Submission Portal.
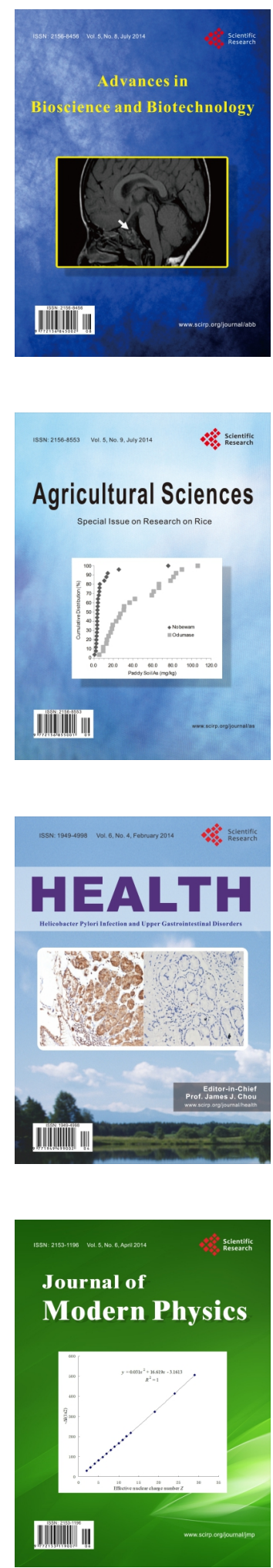
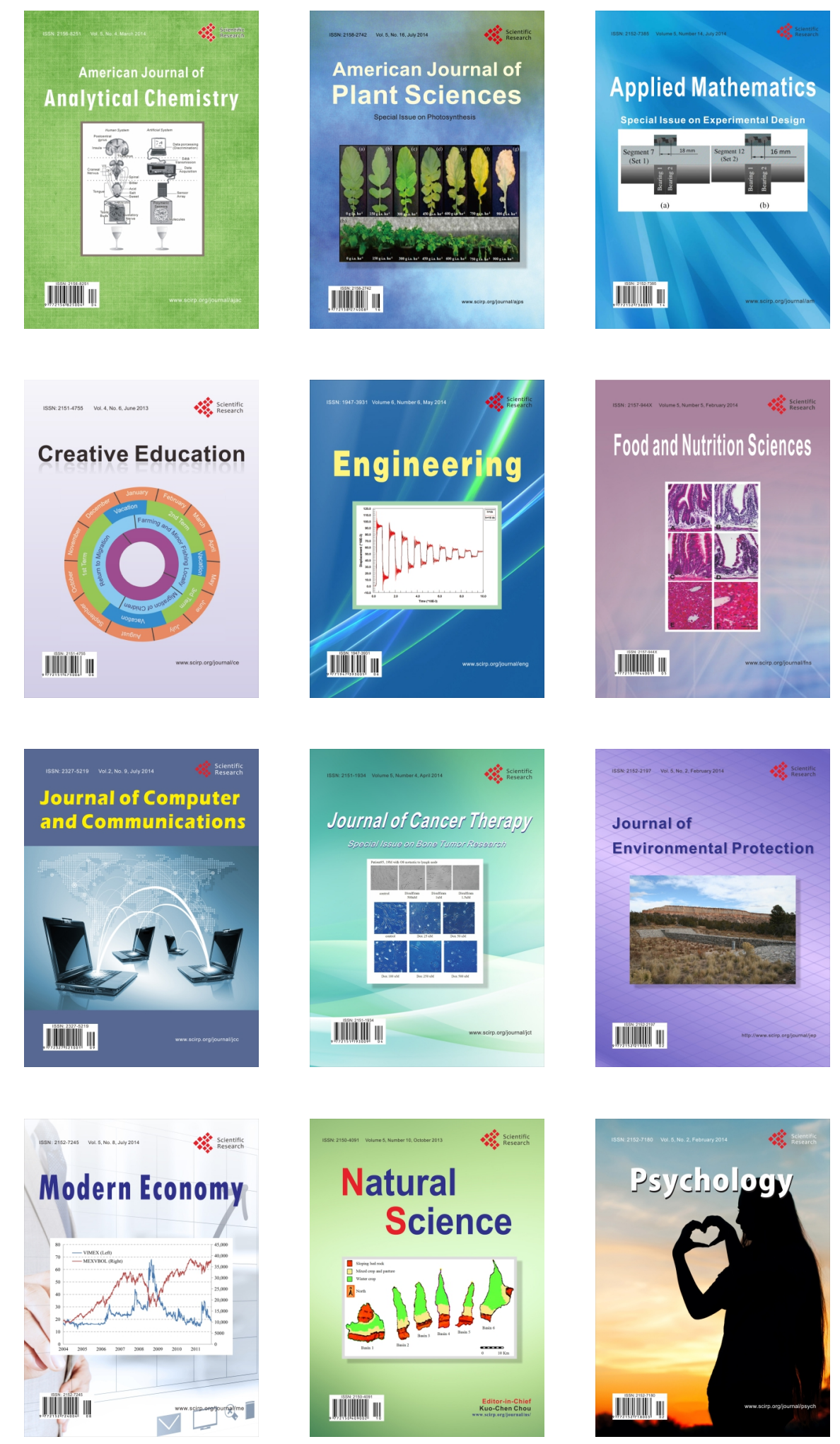